STATE OF FLORIDA

DEPARTMENT OF NATURAL RESOURCES

Tom Gardner, Executive Director

DIVISION OF RESOURCE MANAGEMENT

Jeremy A. Craft, Director

FLORIDA GEOLOGICAL SURVEY

Walter Schmidt, State Geologist

OPEN FILE REPORT 34

THE GEOLOGY AND GEOMORPHOLOGY OF FLORIDA'S COASTAL MARSHES

By

Frank R. Rupert and Jonathan D. Arthur

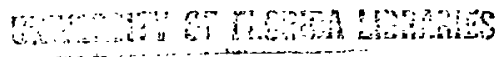

FLORIDA GEOLOGICAL SURVEY

Tallahassee, Florida 


$$
\begin{aligned}
& \therefore 1 \\
& +1 \\
& \therefore b 1 \\
& \text { and }
\end{aligned}
$$

earever

LIBD: 


\section{The geology and geomorphology of Florida's Gulf coastal marshes \\ by}

Frank R. Rupert, P.G. No. 149, and Jonathan D. Arthur, P.G. No. 1149.

\section{GEOLOGY}

Florida is situated in the eastern Gulf of Mexico sedimentary basin, a broad region of sediment accumulation comprised of southem Alabama, southern Georgia, Florida, Cuba, and the Bahamas (Puri and Vernon, 1964). The geologic framework of the state includes thousands of meters of Mesozoic (250 to 67 million years ago) and Cenozolc (67 million years ago to the present) marine limestones, dolomites, sands, and clays. These sedimentary rocks in turn rest on Precambrian (600 million years ago and older), and Paleozoic (600 to 250 million years ago) basement rocks, which lie at depths in excess of about $1200 \mathrm{~m}(4000 \mathrm{ft})$ below land surface.

The emergent portion of Florida and the offshore continental shelf and slope areas are comprised principally of Cenozolc marine sedimentary rocks. Most of these rocks were deposited in the shallow seas which covered the Floridlan Platform sporadically during the last 66 million years. Over the millennia, younger rock layers, or formations, were successively deposited on top of the older layers. The result is that Flortda's rock units are stacked "layer cake" style in the subsurface. Many of the layered formations vary locally in thickness, however, or have been tilted, downwarped, or modfied by erosion since the time they were originally deposited. This has resulted In a somewhat complex geologic structure underlying Florida's west coast. Figure 1 is a generalized geologic cross section of the west coast from Pensacola to St. Petersburg. It illustrates the stratigraphy of the near surface formations underlying the coastal marshes, and will serve as a reference in the following discussion of the geology of Florida's Gulf coast. Data used in the construction of the cross section were obtalned from Ithologic logs of well cores and samples on file at the Florida Geological Suney (FGS). The "W-" numbers shown on the cross section represent FGS well accession numbers.

The oldest rocks underlying Florida are known only from samples brought to the surface during the drilling of deep oil test wells. These basement rocks typically range in age from Late Precambrian (about 700 million years ago) to Middle Mesozolc (about 150 million years ago). In the eastern Florida panhandle and northern peninsula, the basement rocks are igneous and sedimentary in nature, and lie below $1200 \mathrm{~m}$ (4000 ft) in depth; in southern Florida, the basement rocks are generally more than $4500 \mathrm{~m}$ $(15,000 \mathrm{ft})$ deep, and are comprised primarily of Middle Mesozoic lgneous rocks (Arthur, 1988).

Overlying the basement rocks are a serles of Mesozoic sedimentary rocks, including sands, shales and limestones. Most are marine in orlgin. Florida's two oil regions, the Jay trend in northwestern Florida, and the Sunniland trend in south Forida, produce oll from horizons within these Mesozolc rocks.

A sequence of Cenozolc (predominantly marine) sediments in turn overlle the Mesozoic rocks. These rocks contain Florida's drinking water aquifers and Industrial mineral deposits, and comprise the visible portions of the state today. Figure 2 is a generallzed stratigraphic chart summarizing the Eocene and younger Cenozoic formations present under west coastal Florida. The Paleocene rocks are marine limestones and dolomites. These older rocks are not important fresh water aquifers, and lie deeper than the depths attained by most water wells. For the purposes of this report, the discussion of the stratlgraphy will be limited to Middle Eocene and younger sediments. Many of these sediments crop out at the surface, and most directly affect the geology and hydrology of Florida's Gulf coastal marsh region. Data on the lithology. depth, thickness, and occurrence of the formations is derived from well logs on file at the Florida Geological Survey.

\section{Middle Eocene Series Avon Park Formation}

The Avon Park Formation (Applin and Applin, 1944; Miller, 1986) is typically a cream to brown to tan, fossiliferous, marine dolomite. It commonly contains pasty limestone beds and 


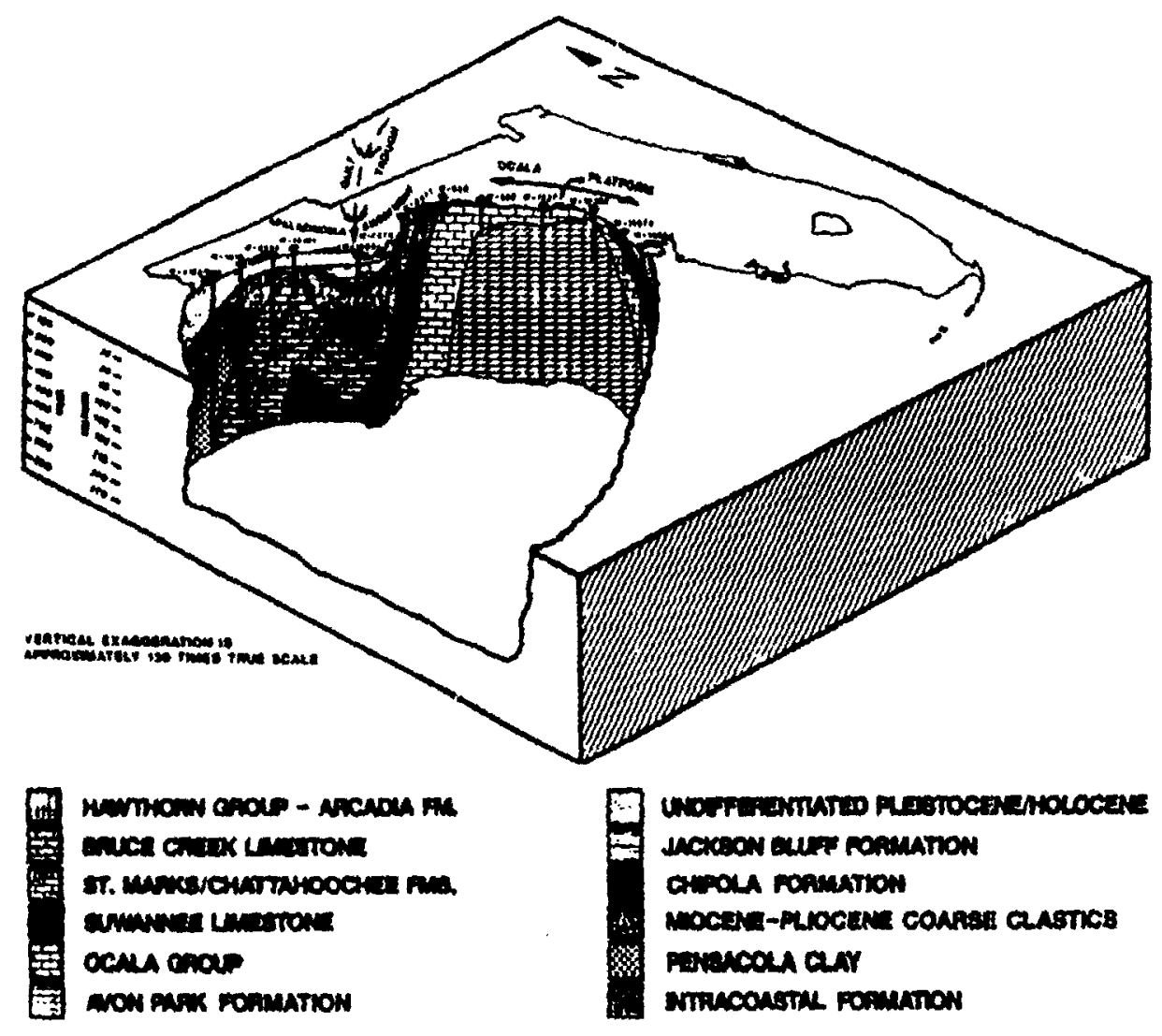

Foure 1. Generilaed gedoglo crose section

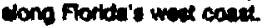

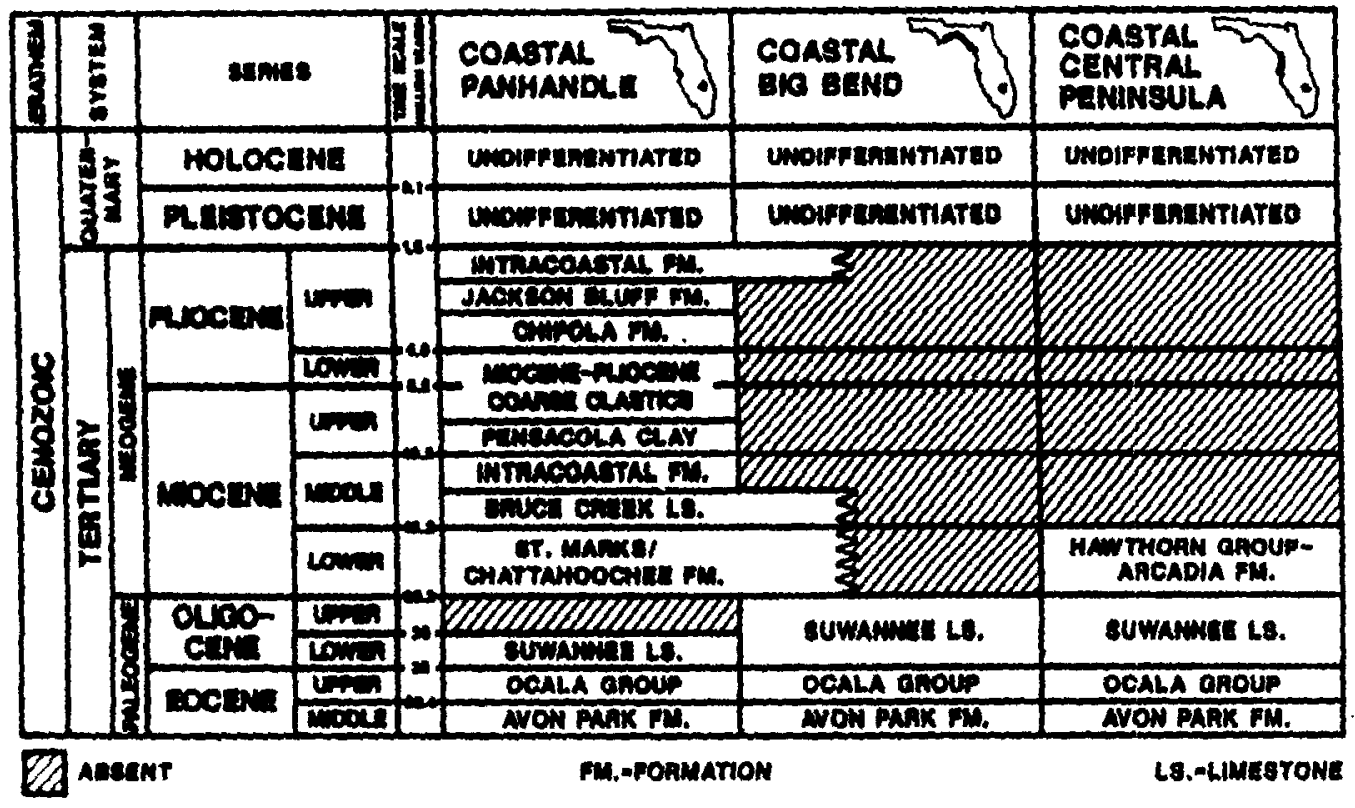

Fine 2. Stratopephe chars of the Eccone and younger formetions undating Florda's Gull comeder marahes 
peat flecks and seams. The Avon Park Formation was deposited in a shallow sea which covered the area of present-day Florida about 54 million years ago. Numerous shallow-water fossils are found in Avon Park Formation sediments, including heart urchins, sand dollars, mollusks, foraminifera, and a "turtle grass-llke" marine plant, very similar to the species Ilving off the Big Bend coastilne today.

The Avon Park Formation is the oldest rock exposed at the surface in Florida. It occurs in west-central Florida along the crest of a gentle, northwest-southeast trending anticlinal feature variously called the Ocala Uplift, Ocala Arch, Ocala High, or Ocala Platform (Puri and Vernon, 1964; Scott, 1988), the origin of which is uncertain. Eocene and younger rocks have been removed by erosion over the structure.

The Avon Park Formation is exposed only in small areas of central and southern Levy County and northernmost Cltrus County, corresponding to the crest of the Ocala Platform (see Figure 1). It dips westward, where it interfingers with the age equivalent Lisbon Formation under the western Florida panhandle. Thickness of the unit in west-central Florda is variable, but generally ranges from 0 to $240 \mathrm{~m}$ (0 to $800 \mathrm{ft}$ ) statewide (Chen, 1965).

Dolomite from the Avon Park is quarried in Citrus and Levy Countles for use in construction materlals. The Avon Park is also a unit of the Floridan aquifer system, one of Florida's primary drinking water aqulfers. It is unconformably overlain by marine limestone of the Upper Eocene Ocala Group.

\section{Upper Eocene Series Ocala Group}

The Late Eocene (38 to 41 million years ago) Ocala Group (Pur, 1957) is composed of three marine limestone formations. In ascending order, these are the Inglis, Williston, and Crystal River Formations, all named for towns in the respective local outcrop areas of each formation. The formations have traditionally been differentlated on the basis of fossil content, and to a lesser extent, lithology. For the purposes of this report, these three units will be referred to collectively as the Ocala Group.

The Ocala Group was deposited in a shallow, Late Eocene sea. It is typically a white to cream, abundantly fossiliferous, chalky to coquinold limestone. Microfossils are generally the most common fossil forms present, especially the large species of foraminifera Lepidocyclina, Nummulites, and Heterostegina. Mollusks, bryozoans, and echinoids are also common in these sediments. As shown on Figure 1, the Ocala Group also crops out in west central Florida, along the crest of the Ocala Platform. It dips generally westward and southwestward from its outcrop area. The thickness of the Ocala Group in west-central Florida averages about 60 $m$ (200 ft), but is locally variable, and generally thins over the crest of the Ocala Platform.

Limestone of the Ocala Group is exposed sporadically or is blanketed only by a thin veneer of Pleistocene and Holocene sands in all of Dixie County and portions of Lafayette, Gilchrist, Levy, Citrus, Marion, and Hernando Counties. Throughout this area it is quarried as construction material and road base.

The exposed surface of the Ocala Group limestone forms a relatively flat-lying, gently seaward-sloping, solution depression and sinkhole-pocked plain over most of its outcrop area. This plain continues offshore onto the broad westem Florida continental shelf. Boulders, pinnacles, and small islands of Ocala Group limestone are common along the Gulf coastline of Dbxle, Levy, and Citrus Countles Nernon, 1951). Many of the coastal marshes in thls area are developed in the thin calcitic muds. silt, organles, and relict marine sands deposited in solution depressions in the underlying limestone (see Figure 3). The Ocala Group is an important unit of the Floridan aquifer system. Along much of the central west coast and within many of the coastal marsh areas, the potentiometric surface of the Floridan aqulfer system is at or above land surface. As a result, numerous seeps and small springs feed freshwater into the marshes. Flow from some of these springs is sufficient to form small tidal creeks and tributaries through the otherwise dense marsh grasses (Nettles, 1976).

\section{Oligocene Series Suwannee Limestone}

The Oligocene (33 to 25 million years old) Suwannee Umestone (Cooke and Mansfield, 1936) is a white to tan, fossiliferous, commonly dolomitic marine limestone, named after exposures along the Suwannee River in northern Florida. As with the preceding Eocene 
formations, the Suwannee was probably deposited in a shallow temperate sea. It contains abundant microfossils, mollusks, echinolds, bryozoans, and rare corals. Early indlans of the reglon used the abundant chert occurring in both the Ocala Group and Suwannee Limestone to fashion tools and weapons. The Suwannee Umestone has been truncated against the flanks of the Ocala Platform (Figure 1), and is exposed at the surface at the northern and southern ends of this feature. It occurs as the surficial unit in eastern Jefferson County, most of Taylor County, westem Hemando County, and northern Pasco County. In these areas, the Suwannee Limestone forms a flat-lying, karstic plain which extends seaward onto the continental shelf. Boulders and pinnacles of Suwannee Lumestone are common along the low energy coasts of Jefferson and Taylor Countles. The Suwannee Limestone is the upper unit of the Floridan aquifer system in tis outcrop area. Small fresh water springs and seeps commonly occur in the marshes of southern Jefferson and Taylor Countles, some forming creaks or contributing to the fiow of rivers such as the Aucilla and Econfina.

\section{Mlocene Series}

The Mlocene Epoch marked a significant change in the depositional regime of the Florida peninsula. Provloualy a shallow carbonate bank, Forida experienced an influx of continental sillciclastic sediments during the Miocene from the continental mainiand to the north. This was due in large part to the closing of a feature called the Suwannes Straits or Gulf Trough, which trended southwestward across the eastem Florda panhandle (Flgure 1). The Gulf Trough was thought poselbly to have been an ancient channel or seeway, existing from the Cretaceous Era through the end of the Ollgocene Epoch (Dall and Harris, 1892; Chen, 1965). It probably connected two major depositional basins, the Southeast Georgla Embayment and the Apalachicola Embayment. Currents within this paleo-strait may have functioned as both a zoological and a sedimentological barrier between the carbonate banks and islands of peninsular Florida and the continental mainland.

Phosphogenesis also occurred on a large scale beginning in the Mlocene. Many Mlocene formations contain phosphate grains, ranging from sitt to pebble size. Florida's economic phosphate deposits are concentrated in the Mlocene Hawthorn Group sediments in the Central Florida Phosphate District of Polk and surrounding counties and in the North Florida Phosphate District in Hamilton County.

The Mlocene formations in Florlda are primarily marine in origin. In contrast to the. nearly pure calcium carbonate limestones of the Eocene, the Mlocene and younger sediments, Including the carbonates, typically contain terrigenous quartz and heavy mineral sands and clays and phosphate. Starting in the Lower Mlocene, a massive influx of river-borne continental sediments poured into the seas covering present day peninsular Florida (Scott, 1988). The Miocene seas reworked and deposited these sediments in a broad blanket over the carbonates of eartier epochs. In the western panhandle, a series of marine limestones and shelly sands were laid down. The Mlocene seas supported a rich marine fauna, as shown by the numerous fossils found in these sediments. Based on fossils, paleoenvironments ranged from shallow nearshore and lagoon to deepwater continental shelf. Many of Florida's commercial mineral deposits, including phosphate and fuller's earth, were formed in these ancient sea floor sediments.

\section{Lower Miocene Series \\ St. Marks Formation}

The St. Marks Formation (Puri and Vernon, 1964) is exposed along the northern Big Bend coastline in Wakulla County. It is the only Mlocene carbonate unit exposed in the coastal marsh zone. This formation is a white to very pale orange to light gray, quartz sandy, fossilliferous marine llmestone. Foraminifera and mollusks are the dominant fossil forms, generally present as molds. Along the coast the St. Marks Formation contains abundant chert, which probably supplied the paleoindlans of the region with tool and spear point material. The St. Marks Formation occurs near or at the surface in most of south central and south eastern Wakulla County. Here it forms a sllghtly seaward-sloping, karstic plain called the Woodville Karst Plain. Thickness varles from $0 \mathrm{~m}$ at the Wakulla-Jefferson County line to over 30m (100 fi) along the eastern flank of the Apalachicola Embayment. Extensive salt marshes, developed in the thin sand and mud veneer overlying the St. 
Marks Formation limestone, border the southern edge of Wakulla County.

The St. Marks Formation is the uppermost unit of the Florldan aquifer system in the eastern panhandle. In southern Wakulla County, the potentiometric surface of this aquifer is at or above the land surface elevation. Many small fresh water springs are scattered through the coastal marshes, and several submarine springs are situated on the offshore extension of the karst plain. The St. Marks pinches out against the underlying Suwannee Limestone to the east in Jefferson County (Figure 1), and dips generally to the west-southwest. To the west under Franklin and Gulf Counties it becomes indistinguishable from the Bruce Creek Limestone. It interfingers to the north and possibly under the western panhandle with the age-equivalent Chattahoochee Formation.

\section{Hawthorn Group Arcadia Formation}

The Lower Mlocene Arcadla Formation of the Hawthom Group (Scott, 1988) underlies the west-central Gulf coast from approximately New Port Richey to Sarasota (Figure 1). This unit is comprised primarily of white to yellowish-gray to light olve-gray limestone and dolomite containing varlable amounts of quartz sand, clay, and phosphate grains. It unconformably overlies the Suwannee Limestone, and is overlain by undifferentiated Pleistocene quartz sands. Hawthorn Group sediments are absent along the panhandle coast.

Hawthorn Group sediments serve as an Intermediate confining unit to the underlying Floridan aquifer system. Locally, carbonates within the Hawthorn Group may also function as an intermediate freshwater aquifer system, or in some areas, are in hydrologic continulty with the underlying Floridan aquifer system and considered part of the Floridan aqulfer.

The Hawthom Group does not crop out in the vicinity of the coastal marshes. It is probably eroding offshore however, as pebbles and cobbles of Hawthorn Group carbonate are often found washed up on Pinellas County beaches.

\section{Middle Miocene}

West of Wakulla County in the panhandle, the Mlocene units dip and thicken southwestward into the Apalachicola Embayment (Figure 1). Both the Lower Miocene St. Marks Formation and the overlying Middle Mlocene Bruce Creek Limestone dip into the trough of the embayment, reaching a maximum local depth and thickness under the axis of the basin. These units shallow again on the western side of the embayment, and attain a depth and thickness similar to that on the eastern edge of the embayment.

\section{Bruce Creek Limestone}

Bruce Creek Limestone was the name given by Huddlestun (1976) to a white to light yellowish-gray, Middle Mlocene marine limestone underlying part of panhandle Florida. It extends from the eastern edge of the Apalachicola Embayment westward, with generally southwest dip. The Bruce Creek Limestone is commonly quartz sandy, phosphoritic, and both micro- and macro-fossiliferous. Fossils are generally preserved as molds. This formation is primarily a subsurface unit, and does not crop out in the vicinity of the coastal marshes. The Bruce Creek Limestone thickens to over $60 \mathrm{~m}$ (200 ft) in the Apalachicola Embayment. Down-dip, it is indistinguishable from the underlying St. Marks Formation. In the central and western panhandle, the Bruce Creek Limestone comprises the uppermost unit of the Floridan aquifer system.

\section{Middle Miocene Through Pliocene Series Intracoastal Formation}

Huddlestun (1976) applied the name Intracoastal Formation to a soft, yellowish-gray to olive green, sandy, highly microfossilferous, argillaceous marine limestone underlying the coastal area of west Florida. This formation extends from easternmost Franklin County westward, and continues to approximately the Santa Rosa County line (Schmidt, 1984). The Intracoastal Formation is predominantly a subsurface unit, dipping and thickening to the west-southwest into the Apalachicola Embayment. It approaches $100 \mathrm{~m}(300 \mathrm{ft})$ in thickness in the trough of the Apalachicola Embayment. The unit shallows and thins west of the embayment, then thickens and dips westward towards the Pensacola area. Analysis of the microfossils present indicate an age range for the Intracoastal Formation of Middle Mlocene (down dip) to Late Pllocene (in the up-dip portions), with a hiatus 
separating the age extremes. Locally it occurs close to the surface in the central panhandle, but does not crop out in the coastal marsh region.

\section{Pensacola Clay}

The Pensacola Clay (Marsh, 1966) is a pale, yellowlah-brown to olve-gray, dense, silty, commonly quartz-rich sandy clay. This unit is reatricted to the subsurface, occurring under the panhandle from approximately Okaloosa County weetwand into Alabama. It thickens rapidly to the south and weat (see Figure 1), reaching a maximum thickness of about $150 \mathrm{~m}(500 \mathrm{ft})$ under Pensacola Bay (Clark and Schmidt, 1982). The Pensacola Clay is considered Late Mlocene in age, overlying the Bruce Creek Limestone, and is interfingered locally with the Intracoastal Formation or the Mlocene Coarse Clastics (Clark and Schmidt, 1982).

\section{Mloceno-Pliocene Coarse Clastics}

Marsh (1986) proposed the name Mlocene Coarse Clastics for a serles of sands, gravel, clays, and shell beds underlying the westem panhandle. These sediments are largely comprised of light-gray to palo-yellowish-brown quart sand and gravel, with minor clay and marine mollusk shells. The Mlocene-Pllocene Coarse Clastics occur from western Okaloosa County westward through Santa Rosa and Escamble Countles. Thickness of this unit reaches nearly $150 \mathrm{~m}$ (500 ti) under Santa Rosa County. The coarse clastics overlie the Pensacola clay and Intracoastal Formations, and locally may be contemporaneous (Late Mlocene to Earty Pllocene in age) with portions of both formations; they are overiain by undifferentiated Pletatocene sand (Clark and Schmidt, 1982).

\section{Chipola Formation}

The Chipola Formation (Puri and Vernon, 1984) is present at depth under the coastal marshes in the vicinity of Gulf County, along the axis of the Apalachicola Embayment. Lithologically, it is comprised of a yellowish-gray to Ilght-gray, quartz sandy marine limestone. Foraminifera and mollusks are typically the most abundant fossils. Thickness of this unit reaches about $15 \mathrm{~m}(50 \mathrm{ft})$ in the central Apalachicola Embayment, thinning and pinching out to the west and east of the embayment. In the downdip coastal and offshore areas, the Chipola Formation overlles the Intracoastal Formation and is considered to be late Pllocene in age (Schmidt, 1984). It is unconformably overlain by the Jackson Bluff Formation.

\section{Jackson Bluff Formation}

The Late Pllocene Jackson Bluff Formation (Purl and Vernon, 1964) consists of tan to oranglsh-brown to graylsh green sandy, clayey shell beds. It is restricted in occurrence to the central Apalachicola Embayment, where the unit reaches about $30 \mathrm{~m}$ (100 ft) in thickness. The Jackson Bluff Formation overlles the Chipola and Intracoastal Formations, and is in turn overlain by undifferentlated Pleistocene and Holocene sands. The Jackson Bluff Formation does not crop out in the coastal marshes.

\section{Plelstocene and Holocene Serles}

A serles of undfferentlated Plelstocene (1.8 millon to 10,000 years old) and Holocene $(10,000$ years and younger) quartz sands, clayey sands, and sandy clays blanket the older formations along much of Florlda's west coast. These sediments are composed largely of reworked rellict Plelstocene marine sands and Holocene alluvium, calcitic muds, and organics.

The Pleistocene Epoch, or "lce Age", was characterized by four great glacial periods. During thls epoch, global temperatures cooled, and huge lce sheets grew southward from Canada. Large quantities of seawater were consumed to build the glaciers, and sea level dropped as much as $130 \mathrm{~m}$ (400 ft). Each glaclal period was punctuated by warmer interglaclal periods during which the sea level rose, at times to over $30 \mathrm{~m}$ (100 ft) above modern level. As the Pleistocene seas transgressed inland, wave and current actlvity eroded, reworked, and redeposited the sands of earlier formations. At the same time, rivers and an active southwardmoving littoral drfft system brought new clastic sediments into Florida. The Big Bend Area was a drowned karst coastline during the Pleistocene sea-level highstands. Planing by wave action and In-filling of the karst features with sand resulted in the flat, seaward-sloping plain characterizing this reglon today. Figure 3 illustrates a typical nearsurface cross-section in the coastal marsh zone 


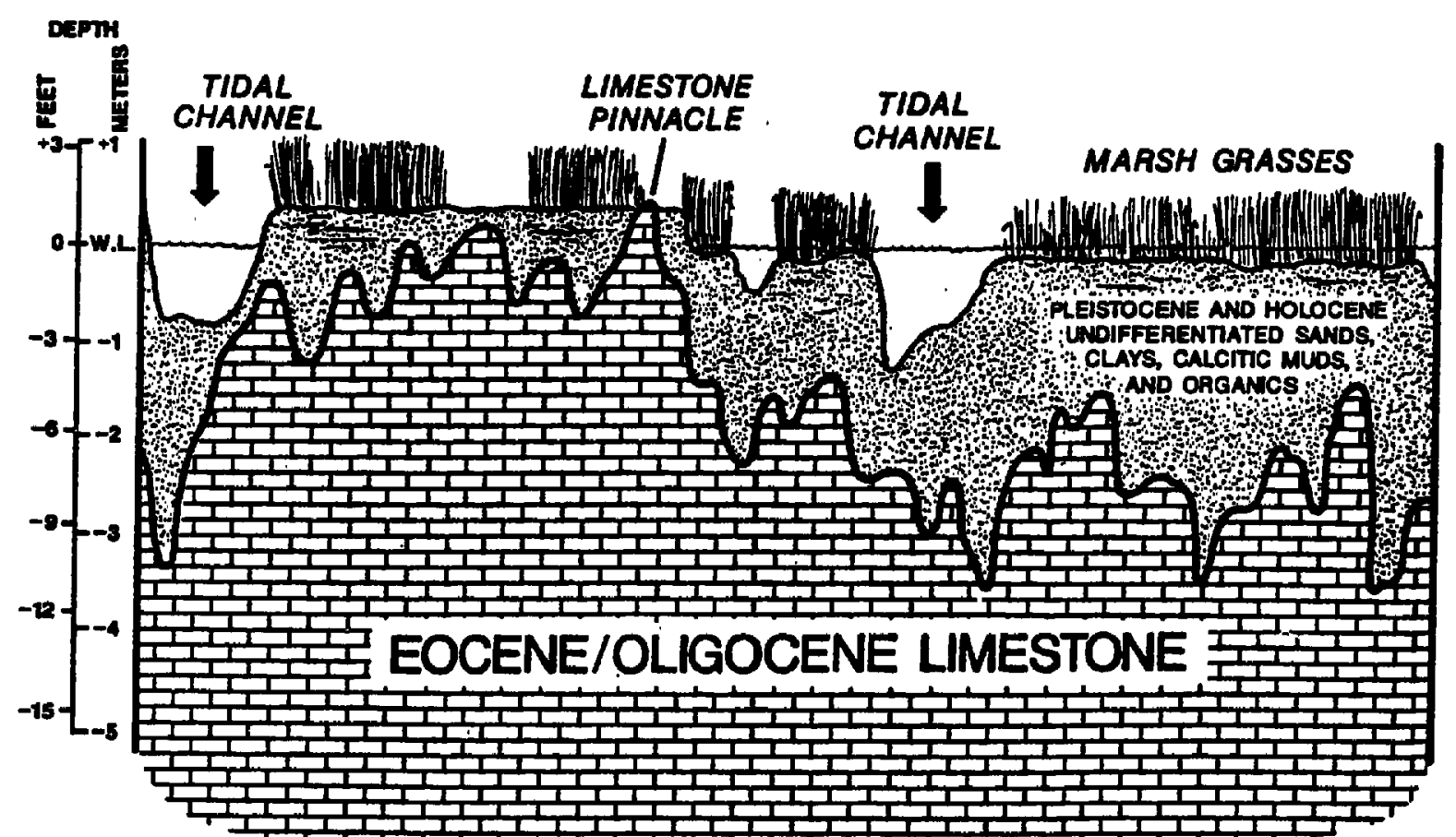

$\int_{300}^{000}$ metrens

Figure 3. Generalized near-surface cross section in the coastal marshes, west-central Florida (modified from Hine and Belknap, 1986). 
along the west-central Florida coast. The l.arstlc, irregular surface of the underlying limestone is infilled with Pleistocene and Holocene sediments, with a few llmestone pinnacles exposed at the surface. The younger sands, muds, and silts form a substrate for many of the coastal marshes in this area.

Rellct dunes, bars, and barrler lsland sand bodles, left by retreating Pleistocene seas, also are common features today along much of Florda's central and northern Gulf coasts. In the central panhandle, the ancestral Apalachicola Alver meandered over a large area of Bay and Gulf Countles during the Pleistocene and Holocene, leaving in its wake rellct levee deposits and alluvium. Much of the surficial and nearsurface sediments in the central and western panhandle coastal areas are a mixture of marine and alluvial sands and clays.

The Pleistocene deposits are thinnest in the Big Bend area. where limestone is near or at the surface. West of Wakulla County, these Pleistocene sediments thicken to nearly $60 \mathrm{~m}$ (200 it) near the Alabama state line.

Holocene sand depostilon continues today. Accumulation of these deposits is primarlly concentrated along the banks, bottoms, and mouths of the major Gulf coast rivers, such as the Apalachicola, Ochlockonee, Aucilla, Suwannee, and Whilacoochee. In portions of the central west coast and Big Bend areas, a Holocene interibal calcitic mud often overlles the Pleistocene sand (Nettles, 1976). Organics dertved from decaying marsh grasses are intermbxed with sandy typically forms the surface layer in the coastal marshes (Hine and Belknap. 1986).

\section{GEOMORPHOLOGY}

The geomorphology of Florida's Gulf Coast has been shaped primarily by coastal processes and sea-level changes during the past flve million years. These sea-level changes have caused shifts in ground water lovels, which in turn have enhanced the development of karst landforms during this time. The karst features have thus altered some of the original shoreline erosional and depositional features within the Gulf Coast reglon. Discussion of these two interrelated geomorphic features is limited to an Inland distance of 16 kllometers (10 miles), spanning the study area from Pensacola to St. Petersburg. In that the focus herein is on the recent geologic past, modern offshore landforms such as spits, barrier Islands and bars are not dlscussed.

Up to six marine terraces are reported to occur within the reglon of interest (Cooke, 1945; Healy, 1975). As defined by Garner (1974), a marine terrace is a surface of erosion or depositlon formed along a coast by wave action. These terraces represent the floors of ancient shallow seas and are situated in a step-like manner, roughly parallel to the present-day coast. Each "step" is a topographic break ranging from a gentle slope to a sharp Incline. Where sharp, these changes in topography which separate two terraces are well preserved seaward-facing wave cut scarps, some of which are regional in extent and contain up to 15 meters (50 feet) of rellef (e.g. the Cody Scarp, Puri and Vernon, 1964, p.11). Although there are fow of this magnitude proximal to the Gulf Coast, coastal terraces and scarps appear to control surface drainage in localized areas. For example, Healy's (1975) Silver Bluff terrace generally coincides with the locatlon of several Gulf coastal swamps.

Early marine terrace studies have applied physiographic and geomorphlc evldence (White, 1970), aerlal photography (Vernon, 1951), sedimentology/stratigraphy (Altschuler and Young, 1960; Plrkle and others, 1970), fleld mapping (Parker and others, 1955) and fossil evldence (Alt and Brooks, 1965). Although conclusions drawn for localized areas are well constrained by these data, studies based on elevation correlations over large areas (e.g. MacNell, 1950; Healy, 1975) should be considered with reservation. Glven the possibility of regional Pllocene-Pleistocene warping (Winker and Howard, 1977a, 1977b), the predominance of karst development in the reglon (White, 1970) as well as other erosional processes, some of these long-distance correlations may not be valid. For example, a present day low-lying area may appear to correlate with a certain low elevation terrace, whereas in fact it may have been an upland or higher elevation terrace which was subsequently lowered by subsurface limestone dissolution. On the other hand, a "young", low elevation terrace may have undergone epeirogenic uplift and now topographically correlates with a higher elevation, older terrace. Thus, the correlation between swamps/marshlands and the Sllver Bluff terrace may be an artifact of the manner in which some terraces have been dellneated. Ancient marine 
scarps and terraces do exist in the Gulf Coast region; however, further study is required in order to more accurately define their occurrence and extent.

Pliocene-Pleistocene sea-level fluctuations are the primary reason for the presence of these terraces (Winker and Howard, 1977a, 1977b). During the Plelstocene "Ice Age" when the fluctuations became more prevalent, four major glaclal cycles occurred due to major climatic changes. As glaclers spread over the continents, sea-level dropped. During periods of melting or interglacial periods, sea-level rose. Healy (1975) and MacNeil (1950) suggested that during subsequent (younger) interglacial perlods, the seas stood at levels below that of the prior event, thus preserving the earlier formed terraces and scarps. Several authors have recognized that glacial melting alone cannot account for the present-day anomalously high elevations of the older marine terraces. Tanner $(1968,1985)$ and Winker and Howard (1977a, 1977b) document evidence for regional uplift during this time.

In a study entitled "The Geomorphology of the Florida Peninsula," White (1970) subdlvided the region into a series of uplands and lowlands.

Most of the present study area lies within a single, major physlographic province: the Gulf Coastal Lowlands (Figure 4). This province stretches from the western Florida panhandle to southern peninsular Florida and averages 40 kllometers (25 miles) in width. Various highlands, ridges or scarps constitute the inland limits of the Gulf Coastal Lowlands, whereas the present-day shoreline marks the seaward boundary. Unllke eastern coastal areas of Florida, this geomorphic province does not correspond to any specific marine terrace delineated by. Healy (1975). The Gulf Coastal Lowlands contain various erosional and depositional landforms that occurred in response to Pliocene-Pleistocene sea-levet. fluctuations. Several relict bars, spits and terraces are superimposed on the modern topography of the region. Subdivisions within the Gulf Coast Lowands include Gulf Barrier Chains, Coastal Swamps, Coastal Lagoons and Estuarles.

Using White's (1970) terminology, the Gulf Coastal Swamps include areas where a deficlency exists in the sand budget for bullding beaches. These low-lying areas correspond to areas on topographic maps where the swamps are immedlately adjacent to the coast. No distinction is made between salt marshes and fresh water swamps. Where isolated patches of swamp are separated from the coast by dry land, the term "coastal lagoons" is applied (White, 1970). This generalized terminology is being revised based on vegetation, soil type and topography in concurrent investigations (C.L. Coultas, personal communication, 1990).

White (1970) presented a two-fold classification for the Gulf Coast of peninsular Florida. Within the study area, this includes a coastal salient that extends from Tampa Bay north to the southern part of Pasco County, and a coastal reentrant spanning from this point north toward Apalachee Bay. The salient is characterized by a relatively steep offshore proflle which allows wave energy to transport, deposit and erode sand along the shoreline. This coastal area contains many relict barrier bars, beach ridges and lagoons. In contrast, the reentrant offshore profiles have gentle slopes and are floored by limestone. White (1970) suggested that these broad shallow profiles sufficiently dissipate wave energies to account for the sand-starved marshy coasts. The sand deficiency is also due to a lack of sediment transported by the Suwannee River. The very low-energy reentrant coast is virtually free of relict shoreline features.

Along the Florida panhandle coastline, White's (1970) generalization concerning the peninsula's offshore profiles is also applicable. Westward from the west end of Apalachee Bay, the profile is either as steep as or steeper than in the Tampa Bay area. The entire panhandle coastline consists of splts, lagoons, beach ridges and offshore barrier islands. An even steeper offshore slope (ramp) in the central panhandle region has precluded barrier island formation offshore of Walton and the west half of Bay counties (Tanner, 1960). Puri and Vernon's (1964) geomorphic map of the region, which uses White's criteria for landform definitlon, shows no coastal swamps.

Tanner (1960) presented data which quantify energy levels within the study area. Rather than focussing on shelf slope, he reported average annual breaker heights to estimate wave energy. Energy levels of Tanner (1960) are shown on Figure 4. The "zero energy" coast corresponds to the coastal swamps and marshes in the Big Bend area. The lack of both wave energy and thus sediment transport and deposition are the two most significant factors that have allowed swamp/marsh development in the region.

In addition to the regional geomorphic characteristics of the study area, two localized features are noteworthy, both of which pertain to 


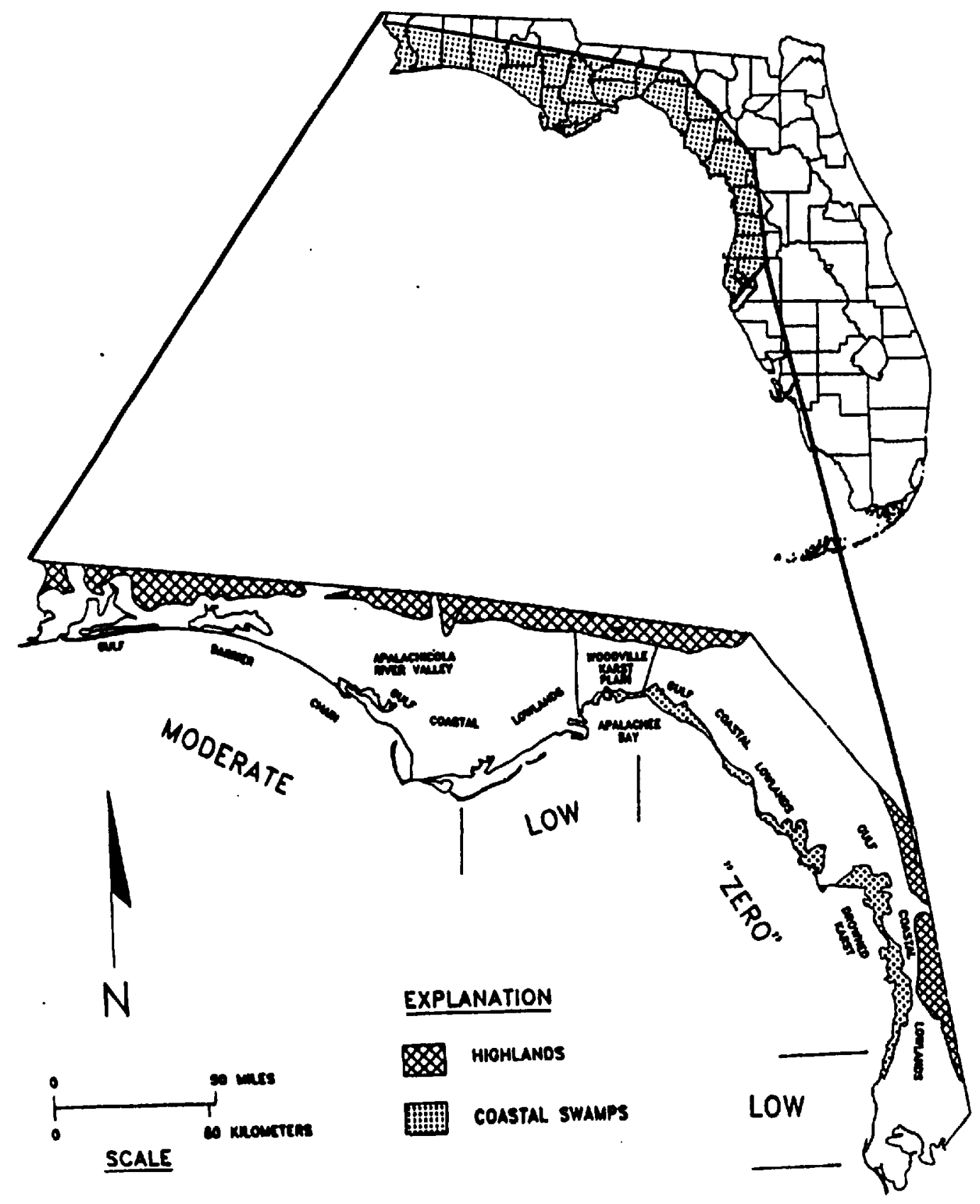

Figure 4. Geomorphic features along study area modifled from White (1970) and Puri and Vernon (1964). Wave energy zones are from Tanner (1960). 
karstification. The first of these can be seen on Tanner's (1960) map which classifies a shoreline region of Cltrus County as "drowned karst" (Figure 4). This area, discussed in detail by Hine and Belknap (1986) is called the Ozello Marsh Archipelago and consists of several limestone cored marsh islands. The outer islands are separated either by creeks or salt marsh vegetation whereas the interior is pocked with circular ponds. Various karstification processes have controlled the shape and orientation of these water bodles (Hine and Belknap, 1986). Figure 3 illustrates the undulatory nature of bedrock limestone in this area due to dissolution.

The Woodville Karst Plain (Hendry and Sproul, 1966) is a subdivision of the Gulf Coastal Lowlands and is located north of the coastal swamp belt in Wakulla County. Portions of the Woodville Karst Plain extend into Jefferson and Leon Countles where it is bounded to the north by the Northern Highlands (Puri and Vernon, 1964). Permeable sands form a veneer over a shallow, southward dipping limestone bedrock. Dissolution of the underlying bedrock, which has probably been occurring ever since the area has been above sea level, has caused subsidence. This somewhat localized depression, and its prevalence of shallow sand filled sinkholes characterizes the Woodville Karst Plain. Although surrounding areas are also underlain by limestone, dissolution has not been prevalent because the overlying sediments contain clays which both buffer the acidlc rainwater and reduce the amount of percolation. Geologic varlables such as those characterizing the Woodville Karst Plain - bedrock type, sediment composition, and sea level history - are significant in the development of Florida's Gulf Coast geomorphology.

\section{ACKNOWLEDGEMENTS}

The authors would like to thank Ken Campbell, Dr. Walt Schmidt and Dr. Thomas Scott of the Florida Geological Survey, and Dr. William F. Tanner of Florida State University for critically reviewing the manuscript of this report.

\section{REFERENCES}

Alt, D. and Brooks, H. K. 1965. Age of the Florida marine terraces: Journal of Geology 73:406-411.
Altschuler, Z. S. and Young, E. J. 1960. Residual origin of the "Plelstocene" sand mantle in central Florida uplands and its bearing on marine terraces and Cenozoic uplift: U.S. Geological Survey Professional Paper 400-B:202-207.

Applin, P. L, and Applin, E. R., 1944, Regional subsurface stratigraphy and structure of Florida and southern Georgia: American Association of Petroleum Geologist Bulletin, 28:1673-1753.

Arthur, J. D., 1988, Petrogenesis of Early Mesozoic tholelite in the Florida basement and an overview of Florida basement geology: Florida Geological Survey Report of Investigation 97.

Chen, C. S., 1965, The regional lithostratigraphic analysis of Paleocene and Eocene rocks of Florida: Florida Geological Survey Bulletin 45.

Clark, M., and Schmidt, W., 1982, Shallow stratigraphy of Okaloosa County and vicinity, Florida: Florida Bureau of Geology Report of Investigation 92.

Cooke, C. W., 1945,. Geology of Florida: Florida Geological Survey Bulletin 29.

, and Mansfield, W. C., 1936, Suwannee Limestone of Florida [abs.]: Geological Society of America Proceedings for 1935.

Dall, W. H., and Harris, G. D., 1892, Correlation papers - Neocene: U. S. Geological Survey Bulletin 84.

Garner, H. F. 1974. The origin of landscapes. Oxtord University Press. New York.

Healy, H. G. 1975. Terraces and shorelines of Florida: Florida Geological Survey Map Series 71.

Hendry, C. W. and Sproul, C. 1966. Geology and ground-water resources of Leon County, Florida: Forida Geological Survey Bulletin 47.

Hine, A. C., and Belknap, D. F., 1986, Recent geological history and modern sedimentary processes of the Pasco, Hernando, and Citrus County coastline: west central Florida: Florida Sea Grant College Report No. 79.

Huddlestun, P. F., 1976, The Neogene stratigraphy of the central Florida panhandle. [Ph.D. dissert.]: Tallahassee, Florida, Florida State University.

MacNell, F. S. 1950 . Pleistocene terraces and shorellnes in Florida: U.S. Geological 
Survey Professional Paper 221-F.

Marsh, O. T., 1968, Geology of Escambla and Santa Rosa Counties, western Florida panhandle: Florlda Geologlcal Survey Bulletin 46.

Miller, J. A., 1986, Hydrogeologle framework of the Floridan aquifer syotem in Florlda and in parts of Georgla, Alabama, and South Carolina: U. S. Geologlcal Survey Prolwacional Paper 1403-B.

Netrles, S., 1976, Imertidal calcitic muds along the west coast of Florida [theals], Department of Geolooy, University of Forlda, Galneoville, Florida.

Parker, G. G., Ferquson, G. E. and Love, S. K. 1968. Water resources of southeastern Florida wth special reference to the geology and ground water of the Mlamiarea. U.S. Geological Survey Water-Supply Paper 1256.

Pirke, E. C., Yoho, W. H. and Hendry, C. W. 1970. Anclent sea lovel standa in Florida: Forida Burcau of Geology Bullotin 62.

Purl, H. S., 1967, Stratloraphy and zonation of the Ocala Group: Forida Goologlcal Survey Bulletin 38. , and Vernon, R. O., 1984, Geology of Florlda and a guldebook to the claselc expocures: Florida Geological Survey Spectal Publlication 3 (revlsed).

Schmldt, W., and Clark, M., 1980, Geology of Bay County, Fordda: Florida Bureau of Geology Bulletin 57.

1984, Neogene stratlgraphy and geclogic history of the Apalachicola embayment, Florlda: Florida Geological Survoy Bulletin 58.

Scoft, T. M., 1888, The Itthoatratloraphy of the Hawthom Croup (Mloceno) of Florida: Florda Ceologlcal Survey Bulletin 89.

Tanner, W.F., 1900, Florlda coustal clasalfication: Tranaactions - Gulf Coast Association of Ceologlcal Socletles 10:259-268.

1968, Tertlary sea level
symposium. Introductlon:
Paleogeography, Paleoclimatology,
Paleocology 5:7-14.
1986, Late Cenozole sea lovel hivion in the Southeastem United States: Inathute for Tertlary-Quaternary Studles TEA-QUA Sympoalum Series 1:3-8.

Vernon, R. O., 1861, Geology of Clirus and Levy Countiea, Florida: Florlda Geological
Survey Bulletin 33.

White, W. A. 1970. The geomorphology of the Florida Peninsula: Florida Bureau of Goology Bulletin 51.

Winker, C. D. and Howard, J. D., 1977a, Correlation of tectonically deformed shorelines on the southern Atlantic coastal Plain: Geology 5:123-127.

1977b,

Pllo-Plelstocene paleogeography of the Florida Gulf Coast Interpreted from rellct shorellnes: Transactions - Gulf Coast Association of Geological Societies 27:409-420. 



\section{FLORIDA GEOLOGICAL SURVEY}

\section{COPYRIGHT NOTICE}

(9) [year of publication as printed] Florida Geological Survey [source text]

The Florida Geological Survey holds all rights to the source text of this electronic resource on behalf of the State of Florida. The Florida Geological Survey shall be considered the copyright holder for the text of this publication.

Under the Statutes of the State of Florida (FS 257.05; 257.105, and 377.075), the Florida Geologic Survey (Tallahassee, FL), publisher of the Florida Geologic Survey, as a division of state government, makes its documents public (i.e., published) and extends to the state's official agencies and libraries, including the University of Florida's Smathers Libraries, rights of reproduction.

The Florida Geological Survey has made its publications available to the University of Florida, on behalf of the State University System of Florida, for the purpose of digitization and Internet distribution.

The Florida Geological Survey reserves all rights to its publications. All uses, excluding those made under "fair use" provisions of U.S. copyright legislation (U.S. Code, Title 17, Section 107), are restricted. Contact the Florida Geological Survey for additional information and permissions. 